UNTAG Law Review (ULREV)

Volume 3, Issue 2, November 2019, PP 145-150

ISSN 2549-4910 (online) \& ISSN 2579-5279 (print)

http://jurnal.untagsmg.ac.id/indeks.php/ulrev/indeks

www.fakhukum.untagsmg.ac.id

\title{
STUDY OF CHILD PROTECTION FOR SEXUAL EXPLOITATION THROUGH CYBERPORN
}

\author{
Hervina Puspitosari \\ Faculty of Law Universitas Pembangunan Nasional "Veteran” Jawa Timur \\ Email : hervina.ih@upnjatim.ac.id
}

\begin{abstract}
Technological developments have changed human behavior that brings both positive and negative impacts. Misuse of information technology is characterized by the development of cybercrime and the increasingly widespread cases of cyberporn. Especially cyberporn which involves children as victims so that there needs to be attention from the government to protect children from the circulation of cyberporn and become victims of irresponsible cyberporn business people by exploiting children. Sexual crime and exploitation of children through cyber are now so troubling that prevention efforts are needed so that children do not become more victims so that the government, family, community and law enforcement must pay close attention. The perpetrators are using technological sophistication through digital cameras and cell phones and social media to capture potential child victims of cyberporn crime. Photos of the child can be quickly published on the internet.
\end{abstract}

Keywords: Child Protection, Exploitation, Cyberporn

\section{INTRODUCTION}

Law in its development is not only used to regulate existing behaviors in society and maintain existing patterns of habit but more than that, the law leads to their use as a means. To implement the objectives that have been selected and determined so that they can be realized in the community, some means is needed. One of the adequate means is the law with various forms of existing laws and regulations. ${ }^{1}$ The problem of crime is one of the social problems that is always interesting and demands serious attention from time to time. Even more. according to general assumptions and several observations and researches of various parties, there is a tendency to increase from certain forms and types of crime, both in quality and quantity. ${ }^{2}$

1 Bambang Sunggono, Law and Public Policy, Sinar Grafika, no year, P.76. Jakarta. Law is the norm that directs people to achieve certain ideals and circumstances by not ignoring the world of reality. Therefore the law is mainly made with full awareness by the state and is used to achieve a certain goal.

2 Moh. Kemal Darmawan, Crime Prevention Strategy, Citra Bakti. Bandung, 1994, Hal. 1 
Technological developments have changed human behavior that brings both positive and negative impacts. Misuse of information technology is characterized by the development of cybercrime and the increasingly widespread cases of cyberporn. Especially cyberporn which involves children as victims so that there needs to be attention from the government to protect children from the circulation of cyberporn and become victims of irresponsible cyberporn business people by exploiting children.

As of May 2019 there were around 236 cases of pornography, including sexual abuse in which children were victims. The age range of child abuse victims is around 9 to 14 years. And 90 percent of them are done by the closest person. According to records from the Indonesian Child Protection Commission (KPAI), cases related to child sexual crimes in 2018, there were 458 complaints. Of the umpteenth number of these cases 116 complaints were children as victims of online sexual crimes, 134 complaints of children as victims of pornography from social media, and 96 complaints of children as perpetrators of sexual violence online and 112 complaints of children were perpetrators of possession of pornographic media. ${ }^{3}$

Humans as certain cultural creatures in themselves have an awareness of values, because in culture includes everything as it is or das sein and also includes the realm of the world or das Sollen, because humans basically accept what is there but in addition it also seeks what is there should be. ${ }^{4}$ Koesnoe who argues that in human life values are of many kinds and kinds, that is, values of truth, values of decency, there are values of beauty, there are values of law, there are values of sanctity. ${ }^{5}$

Value is the quality of a thing that makes it liked, desired, pursued, valued useful and can make people who live it with dignity, value is a preference reflected by behavior and values will always be associated with goodness, virtue and nobility and will be something that is respected and respected and pursued by someone so that he feels satisfaction and feels to be a perfect human being ${ }^{6}$

Sexual crime and exploitation of children through cyber are now so troubling that prevention efforts need to be taken so that children do not become more victims so they need great attention from the government, family environment, society and law enforcement.

\section{Research Methods}

Type of writing is normative. Normative Legal Research according to Johnny Ibrahim is a

3 https://www.cnnindonesia.com/national/20190803195708-12-418125/polri-sebut-236-kasus-pornografiterjadi-

4 throughout-2019 Soejadi, Pancasila As a Source of Legal Order, Lukman Offset, Yogyakarta, 1999, Hal . 20

5 Ibid, 23

6 Pg.Sutarjo Adisusilo, JR, Learning Character Values, Jakarta, Rajawali Press, 2013, Pg. 56-57. 
scientific research procedure to find the truth based on legal scientific logic from the normative side. The scientific logic that is steady in normative legal research is built on the scientific discipline of law whose object is law itself. ${ }^{7}$ So that the normative legal approach is used in an effort to analyze the problem of legal protection for children as victims of cyberporn by referring to legal norms set forth in legislation, international conventions and in court decisions (jurisprudence). In connection with the type of research used is normative legal research, so in this study the authors used four approaches, namely: (1) the statute approach; (2) a case approach (casesapproach); (3) conceptual approach (conceptual approach); and (4)comparative approach. Statute approach. As a normative legal research, it certainly uses astatute approach, this is because what is examined is various legal rules which are the focus as well as the central theme of a study. ${ }^{8}$ This is as said by Peter Mahmud, that thestatute approachis an approach using legislation and regulation. ${ }^{9}$ Thestatute approach isused by the authors to examine and analyze various laws and regulations governing the legal protection of cybeporn children.

Case approach (cases approach). In normative legal research, thecase approach has the objective to study the application of legal norms carried out in legal practice. Especially regarding cases that have been decided as can be seen in the jurisprudence of cases which are the focus of research. ${ }^{10}$ Thus, in the use of the case approach, the writer needs to understand the ratio decidendi, the legal reasons used by the judge to arrive at the decision. ${ }^{11}$

In this research, thecase approach isused by the author to analyze several court decisions regarding legal protection for children victims of cyberporn crime.

Conceptual approach (conceptual approach). A conceptual approach was used in this study to examine and analyze what is meant by the concept of legal protection, the concept of victims, and also the concept of restitution and compensation. This deepening is needed to differentiate the character of these concepts in terms of the laws and regulations in Indonesia with international conventions. Therefore the writer needs to examine the views of legal scholars regarding this matter. (Comparative approachcomparative approach). In normative legal research a comparative approach is carried out by conducting a comparative study of law. According to Van Apeldoorn, comparative law is an auxiliary science for dogmatic jurisprudence in the sense that to weigh and assess the legal rules and court decisions that exist with other legal systems. ${ }^{12}$ (Comparative approachcomparative approach). This research is 7

8 Johnny Ibrahim, Theory and Methodology of Normative Legal Research, Cet. Third, Bayu Media, Malang, 2010, p., 57.

9 Op Citp. 302. "Peter Mahmud Marzuki, Legal Research, Ed. First, Cet. Sixth, Kencana, Jakarta, p.

10 Johnny Ibrahim, Loc Cit, p. 321.

11 Peter Mahmud Marzuki, Loc Cit, p. 119.

12 Peter Mah mud marzuki, Loc Cit, pp. 133. 
used to compare the laws and regulations in Indonesia with international conventions that regulate legal protection for children victims of cyberporn. In addition, acomparative approach isalso used to compare one court's decision with another court's decision regarding a child victim of cyberporn.

\section{Discussion}

Legal protection for children can be interpreted as an effort to protect the law against various freedoms and children's rights (fundamental rights and freedoms of children) as well as various interests related to children's welfare. So the problem of legal protection for children covers a very broad scope. ${ }^{13}$ Meanwhile, by referring to Law Number 23 Year 2002 concerning Child Protection, what is meant by child protection is all activities to guarantee and protect children and their rights so that they live, grow, develop, and participate, optimally in accordance with the dignity and human dignity, and get protection from violence and discrimination.Departing from and restrictions above, the scope of legal protection for children includes: (1) Protection of children's freedom; (2) Protection of children's rights; and (3) Legal protection of all children's interests related to welfare.

Lawrence M. Friedman said that the legal system consists of a legal structure (in the form of a legal institution), a legal entity (legislation) and a legal culture or legal culture. These three components support the operation of the legal system in a country. In social reality, the existence of the legal system contained in society experiences changes as a result of influence, what is called modernization ${ }^{14}$ or globalization either in evolution or revolution. ${ }^{15}$

Child pornography through digital media is increasingly rife with technological sophistication and the development of social media. Cases of child pornography that have occurred are via Skype. The perpetrator through his skype account creates content (photos and videos) about child pornography and transmits images and videos that contain immoral or child pornography. Efforts are needed to strengthen infrastructure facilities for children who are victims of children in order to receive health rehabilitation services, social rehabilitation and assistance to eliminate child trauma so that children can continue to continue in the future.

In the case of online child pornography involving the Facebook group "Candy Loly Group", the Police have arrested four perpetrators as suspects in this case. Two of them are children who are aged 16 and 17 years, while the other two people are adults. ECPAT Indonesia and ICJR

13 Barda Nawawi Arief Some Aspects of Policy Enforcement and Development of Criminal Law, Citra Aditya Bakti, Bandung, 1998, page 153.

14 Modernization is a process of shifting attitudes and mentality as citizens to live according to the demands of the present. (In Arif Gosita, The Problem of Criminal Victims, Bhuana Popular Science, Jakarta, 2004, Page 168

15 Saifullah, "Reflections on Legal Sociology, Refika Aditama", Bandung, 2010, Page 26 
encourage law enforcement officials to use multiple articles in prosecution. It must also ensure that the article used to ensnare suspects is appropriate and in accordance with applicable laws and regulations. Indonesia already has Law Number 44 Year 2008 concerning Pornography, Law Number 19 Year 2016 concerning Amendment to Law Number 11 Year 2008 concerning Electronic Information and Transactions, Law Number 17 Year 2016 concerning Stipulation of Government Regulation in Lieu of Law Law Number 1 of 2016 concerning the Second Amendment to Law Number 23 of 2002 concerning Protection of Children Becomes a Law and the Book of Criminal Law. ${ }^{16}$

The application of layered articles in the cybeporn case against children so that the perpetrators not only upload / distribute child pornography material but also upload content that violates decency, produce child pornography material and sexually assault victims. The case of cyberporn against children is bad for the future of the child and destroys the future of the child.

The perpetrators are using technological sophistication through digital cameras and cell phones and social media to capture potential child victims of cyberporn crime. Photos of the child can be quickly published on the internet.

Efforts to tackle children becoming victims of cyberporn are among others through capturing the role of government institutions, law enforcement and infrastructure including the development of forensic laboratories and enhancing law enforcement resources through training in combating cybercrime and cyberpornography, especially in areas supported by local experts. including in blocking pornographic sites specifically involving children. Need to increase cooperation in efforts to eradicate cyberpornography, especially child pornography through the internet and enforcement through child protection laws to ensnare cyberporn actors involving children. There is a need for rules that concretely protect children from cyberpornography, especially rules for internet service providers in filtering the spread of child pornography through the internet. The monitoring function needs to be improved starting from the level of individuals (self-watching), family, community environment and school environment in the supervision of children of perpetrators who try to involve children for the spread of cyberporn.

\section{Conclusion}

Sexual crime and exploitation of children through cyber are now so troubling that prevention efforts need to be taken so that children do not become more victims so they need great attention from the government, family environment, society and law enforcement. Efforts to tackle children becoming victims of cyberporn are among others through capturing the role of

16 https://icjr.or.id/penegakan-hukum-pornography-children-online-in-cases-candy-loly-group-need-to-usearticle-criminal-layered/ 
government institutions, law enforcement and infrastructure including the development of forensic laboratories and enhancing law enforcement resources through training in combating cybercrime and cyberpornography, especially in areas supported by local experts. including in blocking pornographic sites specifically involving children. Need to increase cooperation in efforts to eradicate cyberpornography, especially child pornography through the internet and enforcement through child protection laws to ensnare cyberporn actors involving children. There is a need for rules that concretely protect children from cyberpornography, especially rules for internet service providers in filtering the spread of child pornography through the internet.

\section{REFERENCES}

ArifGosita. 2004. Problems of crime victims, Bhuana Popular Sciences, Jakarta, 2004

Bambang Sunggono, Without Years. Law and Public Policy, Sinar Grafika

Barda Nawawi Arief. 1998. Some Aspects of Policy Enforcement and Development of Criminal Law, Citra Aditya Bakti, Bandung

Johnny Ibrahim. 2010. Theory and Methodology of Normative Legal Research, Cet. Third, Bayu Media, Malang

Moh. Kemal Darmawan. 1994. Crime Prevention Strategy, Citra Bakti. Bandung

Peter Mahmud Marzuki, Legal Research, Ed. First, Cet. Sixth, Kencana, Jakarta

Saifullah. 2010. Reflections on Legal Sociology, Refika Aditama ", Bandung

Soejadi. 1999. Pancasila As a Source of Legal Order, Lukman Offset, Yogyakarta

Sutarjo Adisusilo, JR 2013. Learning Character-Values, Jakarta, Rajawali Press

https://www.cnnindonesia.com/nasional/20190803195708-12-418125/polri-sebut-236 cases-pornography-happening-throughout-2019

https://icjr.or.id/peregration-hukum-pornography-anak-online-in-cases-candy-loly-grupperlu-using-pasal-pidana-berlapis/ 